\title{
Mechanisms of cancer cell killing by sea cucumber-derived compounds
}

\author{
Teresa Liliana Wargasetia ${ }^{1} \cdot$ Widodo $^{2}$
}

Received: 28 June 2017 / Accepted: 24 August 2017 / Published online: 18 September 2017

(C) The Author(s) 2017. This article is an open access publication

\begin{abstract}
Summary The aim of cancer therapy is to specifically eradicate tumor cells while causing minimal damage to normal tissues and minimal side-effects. Because of this, the use of natural substances with low toxicity is a good option. Sea cucumbers are one of many potential marine animals that contain valuable nutrients and medicinal properties. The medicinal value of sea cucumbers is attributed to the presence of bioactive agents with promising biological and pharmacological properties that include cytotoxic activity, induction of apoptosis, cell cycle arrest, inhibition of tumor growth, antimetastatic and anti-angiogenic properties, and inhibition of drug resistance. This review discusses the mechanisms of cancer cell death induced by sea cucumber-derived compounds with regard to exploring the potential use of these marine natural products for cancer therapy.
\end{abstract}

Keywords Sea cucumbers · Triterpene glycosides · Anti-cancer, apoptosis, metastasis

\section{Introduction}

Cancer is the second leading cause of death worldwide, and the incidence is on the rise in both developing and developed countries [1]. The rapid development of resistance to cancer

Teresa Liliana Wargasetia

Teresa.lw@med.maranatha.edu

1 Faculty of Medicine, Universitas Kristen Maranatha (Maranatha Christian University), Jl. Prof. Drg. Suria Sumantri MPH No. 65 Bandung 40164, Indonesia

2 Biology Department, Faculty of Mathematics and Natural Sciences, The University of Brawijaya, Jl. Veteran, Malang 65145, Indonesia drugs, and the high toxicity and side-effects of some cancer chemotherapy drugs have caused an increase in the demand for new anti-cancer drugs, particularly from natural products [2]. For more than 40 years, natural products have played a prominent role in cancer treatment, either in their native or modified forms [3]. A 15-year survey conducted by the National Cancer Institute of the United States discovered that $4 \%$ of marine species tested (largely animals) contained antitumour properties [4]. Recently, the search for anticancer agents derived from marine natural products has increased [5].

Historically, the marine environment has proven a rich source of potent natural anti-cancer metabolites. Spongothymidine was the first marine-derived substance, found in 1945, to be developed for the treatment of acute myeloid leukemia and lymphoma. Currently, four other marine cytotoxic compounds, including eribulin, trabectedin, cytarabine, and vedotin, have been established as conventional clinical medicines [6].

Sea cucumbers (or holothurians), belonging to the class Holothuroidea, phylum Echinodermata, are marine invertebrates that are found in benthic areas and deep seas. They have a leathery skin and gelatinous body, shaped like soft-bodied cucumbers. Sea cucumbers, also called trepang, bêche-demer, gamat, balate, or haishen (marine ginseng), have long been utilized in food and Asiatic folk medicine [7, 8]. They contain valuable nutrients such as vitamin A, B1, B2, B3, magnesium, calcium, zinc, iron [8], triterpene glycosides (saponins, sti-choposides, frondoside A, cucumariosides, Dsechinoside A) [8-14], fucoidan [15, 16], triterpenoid aglycones (philinopgenin) [17], non-glycosaminoglycan sulfated glycans [18], sulfated polysaccharides [19], non-sulphated triterpene glycosides (variegatusides) [20], sphingoid bases [21], and chondroitin sulfates [22].

Many researchers have reported anti-cancer activity of substances derived from sea cucumbers and have published the 
molecular mechanism of these agents in cancer cells. In this review, we will discuss the anti-cancer activities and molecular mechanisms of bioactive metabolites derived from sea cucumbers. This review is expected to provide new insight into the possible therapeutic activity of bioactive compounds derived from sea cucumbers for the treatment of many different types of cancers.

\section{Cytotoxicity activity}

Anti-cancer agents exhibit cytotoxic activity through blocking or preventing growth or mitosis of cancer cells [5]. The cytotoxic activity of sea cucumber compounds in human tumor cell lines are well established. For example, holothurin A3 and A4, produced by the Holothuria scabra species, were discovered to be highly cytotoxic in human epidermoid carcinoma (KB) and human hepatocellular carcinoma (Hep-G2) cell lines [23]. Similarly, philinopside E, a newly discovered sulfated triterpene glycoside derived from Pentacta quadrangularis, showed potent cytotoxicity $\left(\mathrm{IC}_{50}=0.75-3.50 \mu \mathrm{g} / \mathrm{mL}\right)$ in various tumour cell lines (human leukaemia cells-HL60, mouse lymphocytic leukaemia cells-P388, human non-small lung carcinoma cells-A549, gastric carcinoma cells-MKN28, lung adenocarcinoma cells-SPC-A4, gastric carcinoma cellsSGC7901, human epithelial carcinoma cells-A431, human hepatoma cells-BEL7402, human ovarian carcinomaHO8901, and human fetal lung fibroblasts-W138) [24].

Sea cucumber compounds that induce cytotoxic effects in a broad range of cancer cell lines are presented in Table 1. Table 1 shows that triterpenoid glycosides (saponins) are the most abundant type of metabolites derived from sea cucumbers.

\section{Induction of apoptosis}

Apoptosis is the process of programmed cell death that is characterized by cell shrinkage and morphological changes including membrane blebbing, chromosomal DNA fragmentation, nuclear disintegration, loss of organelle position in the cytoplasm, and translocation of phosphatidylserine to the outer membrane leaflet $[52,53]$. Apoptosis results in the removal of unwanted, old, or injured cells including cancer cells and is, therefore, an important mechanism for tumor suppression [53, 54]. For this reason, reductions in apoptosis or apoptotic resistance play important roles in carcinogenesis. In general, the mechanisms by which reductions in apoptosis or resistance to apoptosis occurs are due to 1) disruptions in the balance between pro-apoptotic and anti-apoptotic proteins, 2) inactivation or loss of caspase activity, or 3 ) impaired death receptor signaling [55].

Induction of apoptosis is one the most prominent markers of cytotoxic antitumor agents. It has been shown that some natural compounds isolated from sea cucumbers induce apoptotic pathways through several different mechanisms to inhibit cancer progression. Marzouqi et al. (2011) found that frondoside A, a saponin isolated from Cucumaria frondosa, increased the sub-G1 (apoptotic) cell fraction through increases in p53, and subsequent induction of the caspase 9 and 3/7 cell death pathways in breast cancer cells [38]. Frondoside A also demonstrated strong anti-tumor activity through induction of apoptosis, increased expression of p21, and through increased activity of caspase 3, 7, and 9 in AsPC1 and S2013 human pancreatic cancer cell lines [39]. Treatment with Frondanol A5, an isopropyl alcohol/water extract of Cucumaria frondosa, induced apoptosis that was associated with $\mathrm{H} 2 \mathrm{AX}$ phosphorylation and led to cleavage of caspase-2 in HCT116 colon cancer cell lines. This study demonstrated the chemopreventive effects of Frondanol A5 against the development of colon cancer [36]. Another study found that a polar fraction of Frondanol A5 potently induced apoptosis in pancreatic cancer cells, AsPC and S2013 [37]. Philinopside A and E, glycosides isolated from Pentacta quadrangularis, reportedly induced apoptosis in mouse Sarcoma-180 tumors and tumor-associated endothelial cells [56, 57]. Stichoposide C, isolated from Thelenota anax, was found to induce apoptosis as demonstrated by mitochondrial injury and induction of signaling pathway disruption of cancer cells in human leukemia and mouse colorectal cancer cells. In this study, Stichoposide $\mathrm{C}$ induced apoptosis in a dosedependent manner through activation of Fas, caspase-3 and caspase- 8 , cleavage of Bid, and mitochondrial damage in cancer cells [58].

Increased levels of reactive oxygen species (ROS) induce cells to undergo apoptosis. Administration of methanolic extracts of Holothuria parva led to increased ROS production, mitochondrial swelling, mitochondrial membrane potential (MMP), and cytochrome $\mathrm{C}$ release in the mitochondria in an animal model of hepatocellular carcinoma [59]. Induction of apoptosis and other mechanisms related to anticancer activity induced by metabolites isolated from sea cucumbers are summarized in Table 2.

\section{Cell cycle arrest}

Mammalian cells progress through several cell cycle phases (G1, S, G2, and metaphase) during cellular division. Cell cycle checkpoints, notable features of cell cycle progression, provide essential surveillance to prevent cells from entering the next phase before the previous phase has been completed [70]. Thus, halting the cell cycle can lead to prevention of cancer cell growth and division and is one of the major strategies for cancer therapy [71].

Cucumarioside A2-2 demonstrated anticancer effects through its ability to cause the arrest of the cell cycle during 
Table 1 Active compounds from sea cucumber

\begin{tabular}{|c|c|c|c|}
\hline Compound & Species & Human cell line tested & Ref. \\
\hline Aqueous extract & Holothuria arenicola & CT26 & {$[25]$} \\
\hline Arguside A & Bohadschia argus & HCT-116 & {$[26]$} \\
\hline Arguside $\mathrm{B}, \mathrm{C}, \mathrm{D}, \mathrm{E}$ & & A549, HCT-116, HepG2, MCF-7 & {$[27][28]$} \\
\hline Bivittoside & Holothuria polii & HCT116, MCF7 & [29] \\
\hline Colochiroside A & Colochirus anceps & p388, HL60, A-549, SpC-A4, MKN28 & {$[30]$} \\
\hline Crude saponin & Holothuria leucospilota & $\mathrm{B} 16 \mathrm{~F} 10$ & {$[31]$} \\
\hline Cucumarioside A2-2 & Cucumaria japonica & Ehrlich ascite carcinoma, HL-60 & [32] [33] \\
\hline Ds-echinoside A & Peasonothuria graeffei & Hep G2 & [14] [34] \\
\hline Echinoside A & Holothuria nobilis & 26 human cell line & [35] \\
\hline Echinoside A & Peasonothuria graeffei & Hep G2 & {$[34]$} \\
\hline Frondanol A5 & Cucumaria frondosa & HCT116, AsPC-1, S2013 & [36] [37] \\
\hline Frondoside $\mathrm{A}$ and $\mathrm{B}$ & & $\begin{array}{l}\text { MDA-MB-23, A549,MDA-MB-435, } \\
\text { MCF-7, HepG2, HL-60, AsPC-1, } \\
\text { AsPC-1, S2013, AsPC-1 }\end{array}$ & $\begin{array}{l}{[38][13][39]} \\
{[33][40][41]}\end{array}$ \\
\hline Frondoside A & Cucumaria okhotensis & THP-1, HeLa, RT112, RT4, HT-1197 & {$[42][43]$} \\
\hline Griseaside A & Holothuria grisea & HL-60, BEL-7402, Molt-4, A549 & [44] \\
\hline Hillasides A and B & Holothuria hilla Lesson & A549, MCF7, IA9, CAKI-1, PC-3, KB & {$[45]$} \\
\hline Holothurin A3 and A4 & Holothuria scabra & KB, Hep-G2 & {$[23]$} \\
\hline Okhotoside B1,B2,B3 & Cucumaria okhotensis & HeLa cervical cancer & {$[42]$} \\
\hline Organic/water extract & Stichopus chloronotus & C33A, A549 & {$[46]$} \\
\hline $\begin{array}{l}\text { Pentactasides I,II, III, } \\
\text { Philinopsides A and B }\end{array}$ & Pentacta quadrangularis & $\begin{array}{l}\text { P-388, A-549, MCF-7, MKN-28, } \\
\text { HCT-116, U87MG }\end{array}$ & [47] \\
\hline Philinopsides E & & P388, HL60, A549, SPC-A4, MKN28 & {$[24]$} \\
\hline Sphingoid bases & Stichopus variegates & Caco-2, DLD-1, WiDr & {$[21]$} \\
\hline Sphingoid bases & Sea cucumber & HepG2 & [48] \\
\hline Stichoposide D & Thelenota anax & HL-60, K562 & [49] \\
\hline Violaceusides A and B & Pseudocolochirus violaceus & HL-60, BEL-7402 & {$[50]$} \\
\hline Stichorrenoside C and B & Stichopus horrens & Hep-G2, KB, LNCaP, MCF7, SK-Mel2 & {$[51]$} \\
\hline
\end{tabular}

A431 human epithelial carcinoma cells, A549 non-small lung carcinoma, AsPC-1 pancreatic cancer, BEL-7402 hepatoma, B16F10 melanoma, Caco-2 colon cancer, CAKI-1 renal cancer. CT26 colon carcinoma, C33A cervical cancer, DLD-1 colon adenocarcinoma, HCT-8 colorectal adenocarcinoma, HCT116 colon cancer, HeLa cervical cancer, Hep G2 hepatocellular liver carcinoma, Hep3B hepatoma, HL-60 leukemia, HO8901 ovarian carcinoma, HT1197 urothelial carcinoma, IA9 ovarian ca, KB epidermoid cancer, KB-VIN vincristine-resistant, K562 leukemia, LNCaP prostate cancer, LNM35 lung cancer, MCF7 breast adenocarcinoma, and MDA-MB-231 Luc-2 breast cancer, MDA-MB-435 breast cancer, MKN-28 gastric cancer, Molt-4 leukemia, NCI-H460-Luc2 lung cancer, PC-3 prostate cancer, p388 leukemia, RT4 urothelial carcinoma, RT112 urothelial carcinoma, TCCSUP urothelial carcinoma, THP-1 leukemia, T-24 urothelial carcinoma, SGC-7901 gastric cancer, SK-Mel2 melanoma, SPC-A4 lung adenocarcinoma, S2013 pancreatic cancer, U87MG glioblastoma, WiDr colon carcinoma, W138 human fetal lung fibroblast, 486p urothelial carcinoma

the DNA synthesis (S) phase and was shown to induce programmed death in Ehrlich carcinoma mouse tumor cells [32]. In another study, Echinoside A and Ds-echinoside A, triterpenoid glycosides isolated from Peasonothuria graeffei, caused the arrest of the cell cycle during the G0/G1 phases in hepatocellular liver carcinoma cells (HepG2). A reverse transcriptase-polymerase chain reaction assay showed that both triterpenoid glycosides increased expression of cellcycle-related genes, including p16, p21, and c-myc, and decreased expression of cyclin D1 [34]. Frondanol A5, an isopropyl alcohol/water extract of Cucumaria frondosa, inhibited growth during the $\mathrm{S}$ and $\mathrm{G} 2 / \mathrm{M}$ phases and led to increased levels of p21WAF1/CIP and decreased levels of Cdc25c [36].
A polar fraction of Frondanol A5 was effective at inducing $\mathrm{G} 2 / \mathrm{M}$ cell cycle arrest, and also potently decreased expression of cyclin A, cyclin B, and Cdc25c in S2013 and AsPC-1 cells [37].

\section{Reduction of tumor growth}

Tumour growth inhibition by Frondoside A was initially demonstrated in a xenograft model using AsPC-1 pancreatic cancer cells [38]. Frondoside A was also shown to inhibit tumour growth and reduce tumor volume by $87 \%$ in an athymic mouse model using MDA-MB-231 breast cancer cells [63]. 
Table 2 Relevant anti-cancer cell effects induced by sea cucumber compounds

\begin{tabular}{|c|c|c|c|}
\hline Compound & Cell effect & Source & Ref. \\
\hline 24-dehydroechino-side A (DHEA) & 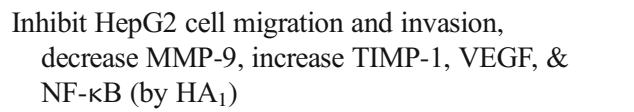 & Pearsonothuria graeffei & {$[60]$} \\
\hline Aqueous extract & Attenuate tumor size, induce intrinsic apoptosis & Holothuria arenicola & {$[25]$} \\
\hline Colochiroside A & Exhibit antitumor activity & Colochirus anceps & {$[30]$} \\
\hline Crude saponin & Induce apoptosis: upregulation of caspase- $3 \& 9$ & Holothuria leucospilota & {$[31]$} \\
\hline Cucumarioside A2-2 & $\begin{array}{l}\text { Inhibit growth of tumor cells multidrug resistance, } \\
\text { induce apoptosis in a caspase-dependent way }\end{array}$ & Cucumaria japonica & [32] [33] [61] \\
\hline Ds-echinoside A & $\begin{array}{l}\text { Suppress migration, MMP-9, and VEGF; cell cycle } \\
\text { arrest (increase p16, p21, and c-myc; decreased } \\
\text { cyclin D1), induce apoptosis by decreased Bcl-2, } \\
\text { NF-kB, and increase TIMP-1 \& caspase-3 }\end{array}$ & Peasonothuria graeffei & {$[14][34]$} \\
\hline Echinoside A & $\begin{array}{l}\text { Induce apoptosis (decrease Bcl-2, and enhance } \\
\text { caspase-3), cell cycle arrest (increase p16, p21, } \\
\text { and c-myc, decrease cyclin D1) }\end{array}$ & $\begin{array}{l}\text { Holothuria nobilis } \\
\quad \text { Peasonothuria graeffei }\end{array}$ & {$[34][35]$} \\
\hline Frondanol A5 & $\begin{array}{l}\text { Increase p21, GiLT expression, macrophage } \\
\text { phagocytosis \& apoptosis }\end{array}$ & Cucumaria frondosa & {$[36][62]$} \\
\hline Polar extract of frondanol A5 & $\begin{array}{l}\text { Decrease expression of cyclin A, cyclin B, and } \\
\text { cdc } 25 \mathrm{c} \text {, and increased expression of } \mathrm{p} 21\end{array}$ & Cucumaria frondosa & {$[36]$} \\
\hline Frondoside A & $\begin{array}{l}\text { Anti-metastatic (by antagonize EP4, TPA-induced } \\
\text { MMP-9 activation via NF-kB and AP-1 signaling), } \\
\text { inhibit tumor cells multidrug resistance, induce } \\
\text { apoptosis (via caspase-3, -8, and -9, PARP, Bax, } \\
\text { p21, p53), inhibit pro-survival autophagy }\end{array}$ & Cucumaria frondosa & $\begin{array}{l}{[13][38][39]} \\
{[43][40][41]} \\
{[61][63][64]}\end{array}$ \\
\hline Glycosides 1 \& 2 & $\begin{array}{l}\text { Activate NF-kappaB and degrade Ikappa B alpha in } \\
\text { A549 tumor cell line (cytotoxic activity) }\end{array}$ & Psolus patagonicus & {$[65]$} \\
\hline Intercedensides $\mathrm{A}, \mathrm{B}$, and $\mathrm{C}$ & Exhibit anti-neoplastic activity & Mensamaria intercedens & {$[66]$} \\
\hline Methanolic extracts & Increase ROS formation, and cytochrome c release & Holothuria parva & [59] \\
\hline Philinopside A & $\begin{array}{l}\text { Inhibit proliferation, migration, angiogenesis, RTKs } \\
\text { in several cell lines }\end{array}$ & Pentacta quadrangularius & {$[56]$} \\
\hline Philinopside E & $\begin{array}{l}\text { Induce cell apoptosis, inhibit tumor growth, } \\
\text { anti-angiogenic via inhibition of } \\
\text { KDR- } \alpha v \beta 3 \text { integrin }\end{array}$ & Pentacta quadrangularius & {$[57][67]$} \\
\hline Sea cucumber fraction & $\begin{array}{l}\text { Exhibit radical scavenging property, inhibit } \\
\text { angiogenesis, and vascularization }\end{array}$ & Sea cucumber & [68] [69] \\
\hline Sphingoid bases & $\begin{array}{l}\text { Induce apoptosis through caspase- } 3 \text { activity, } \\
\text { upregulation of DR5, Bax, GADD } 45 \text {, and PPAR } \gamma \text {, } \\
\text { and downregulation of p-AKT }\end{array}$ & Stichopus variegates & {$[21][48]$} \\
\hline Stichoposide C & $\begin{array}{l}\text { Induce apoptosis of leukemia and colorectal } \\
\text { cancer cells }\end{array}$ & Thelenota anax & {$[58]$} \\
\hline Stichoposide D & Induce cell apoptosis & Thelenota anax & [49] \\
\hline
\end{tabular}

Philinopsides A and E, novel sulfated triterpenoid glycosides derived from Pentacta quadrangulari, were also shown to reduced tumor growth. Philinopside A reduced tumor growth in the sarcoma 180 mouse model, whereas philinopside E inhibited tumor growth in both sarcoma 180 and hepatoma 22 mouse models [56, 57]. Other glycosides that demonstrate the ability to reduce tumor growth are summarized in Table 2 .

\section{Anti-metastatic and anti-angiogenic effects}

Metastasis and angiogenesis are the most dangerous processes acquired by cancer cells. Metastasis is the development of secondary malignant growths at a distance from the primary site of the tumour and one of the principal causes of mortality in cancer patients [14]. Angiogenesis is the formation of new blood vessels from pre-existing vessels that involves the growth, migration, and differentiation of endothelial cells, which line the inside walls of blood vessels. Angiogenesis occurs in tumors to help them to survive and proliferate. Anti-angiogenic agents inhibit this process, thereby preventing the supply of oxygen and nutrients from reaching cancer cell such that tumor cells starve and eventually die [72]. The ability of the cancer drugs to inhibit metastasis and angiogenesis is essential for effective cancer treatment strategies.

Ds-echinoside A, a compound isolated from Pearsonothuria graeffei, caused reductions in cell adhesion, migration, and invasion in HepG2 cells. Immunocytochemical studies revealed that 
treatment with Ds-echinoside A led to decreased expression of matrix metalloproteinase-9 (MMP-9) and resulted in increases in both angiogenesis and metastasis through degradation of the extracellular matrix. Ds-echinoside A also enhanced expression of tissue inhibitors of metalloproteinase-1 (TIMP-1), a crucial regulator of MMP-9 activation. The anti-angiogenic effect of Dsechinoside A was also studied in a series of in vitro and in vivo tumor models. These studies showed that Ds-echinoside A decreased tube formation of human endothelial cells ECV-304 grown in Matrigel and attenuated neovascularization in a chick embryo chorioallantoic membrane (CAM) model [14].

Similar results were obtained by Zhao et al. (2010), in which two sulfated triterpene glycosides, Holothurin A (HA) and 24dehydroechinoside A (DHEA), from Pearsonothuria graeffei were identified. Both of these glycosides showed antimetastatic effects both in vitro and in vivo. The study revealed that HA and DHEA administration reduced adhesion of HepG2 cells and human endothelial cells (ECV-304) grown in Matrigel and inhibited HepG2 cell migration and invasion in a dosedependent manner. Both compounds suppressed tube formation of ECV-304 cells in Matrigel and attenuated neovascularization using the CAM assay. Immunocytochemical analysis showed that both HA and DHEA significantly reduced expression of MMP-9 and increased expression of TIMP-1. Western blot analysis revealed that both compounds markedly suppressed the expression of vascular endothelial growth factor (VEGF). Inhibition of VEGF is a key indicator of anti-angiogenic behavior, displayed by HA and DHEA compounds. Furthermore, only HA downregulated expression of nuclear factor-kappa B (NF-kB). NF-kB regulates expression of MMP-9 such that inhibition of NF- $\mathrm{KB}$ activation suppresses MMP-9 and tumor invasion [73]. This finding suggests that the anti-metastatic activity of saponins derived from $P$. graeffei could be mediated through NF-kB-dependent or -independent pathways, depending on their chemical structures [60].

A study by Ma et al. found that Frondoside A had potent antimetastatic activity in a syngeneic murine model of metastatic breast cancer. Intraperitoneal administration of Frondoside A in mice implanted with mammary tumors in mammary glands, inhibited tumor metastasis to the lungs. Along with the antimetastatic activity described in vivo, Frondoside A also inhibited migration of tumor cells in vitro through inhibition of prostaglandin E receptors, EP2, and EP4 [63].

Other studies have also reported that Frondoside A has the promising anti-metastatic potential for breast cancer therapy. Park et al. investigated the anti-metastatic effects of Frondoside A in MBA-MB-231 human breast cancer cells, and found that Frondoside A inhibited TPA-induced activation of AP-1 and NF-KB and decreased TPA-induced activation of ERK1/2, PI3K/Akt, and p38 MAPK signals caused a reduction in expression of MMP-9 [64]. In addition, Frondoside A decreased invasion of MDA-MB-231 tumour cells in a Matrigel invasion assay [38].
Frondoside A was shown to inhibit angiogenesis as indicated by reduced CD31 staining, used to measure microvessel density, in LNM35 lung cancer xenografts and was shown to block basal and bFGF-induced angiogenesis using the CAM assay. Frondoside A treatment demonstrated significant inhibition of metastasis in a lung cancer xenograft model and an in vitro Matrigel invasion assay, without toxic side effects [13].

\section{Inhibition of drug resistance}

Resistance to chemotherapy is a major problem for cancer therapeutics. One of the major factors that contribute to chemotherapy resistance is a process called autophagy. Pharmacological inhibitors of autophagy are important to prevent the development of resistance to anti-cancer drugs. Frondoside A, a triterpenoid glycoside from Cucumaria okhotensis, inhibited pro-survival autophagy in human urothelial carcinoma cell lines resistant to standard therapies [43].

Another study showed that Frondoside A isolated from the Cucumaria okhotensis and cucumarioside A2-2 isolated from Cucumaria japonica decreased multidrug resistance in the Ehrlich ascites carcinoma mouse tumor model. Frondoside A or cucumarioside A2-2 both demonstrated the ability to form a complex with cholesterol to block membrane transport P-glycoprotein activity in tumor ascites derived from the mouse Ehrlich carcinoma tumor model, resulting in decreased multidrug resistance [61].

\section{Conclusion}

Bioactive compounds isolated from the sea cucumber for use as anti-cancer agents has attracted the attention of cancer researchers because of their natural origin and long history as a nutritious food. Sea cucumbers contain many marine-derived agents that have the potential to inhibit the growth of several different types of human tumor cells as demonstrated in in vitro studies, in vivo murine models, and human studies. Several secondary metabolites derived from sea cucumbers demonstrate anti-cancer properties through multiple mechanisms including cytotoxic activity, induction of apoptosis, cell cycle arrest, reduction of tumor growth, suppression of invasion and metastasis of tumor cells, inhibition of angiogenesis, and decreased drug resistance. Nevertheless, detailed mechanisms of the anti-cancer activities of sea cucumber derivedcompounds remain unclear and comprehensive studies that identify these mechanisms are needed. Above all, the potential anti-cancer activity of bioactive compounds isolated from sea cucumbers gives promising hope for the treatment and prevention of human cancers. 
Funding The work was supported by the Ministry of Research, Technology, and Higher Education of Republic of Indonesia under Postdoctoral Research Scheme in 2017.

\section{Compliance with ethical standards}

Conflict of interest All authors declare to have no conflict of interest regarding the article.

Ethical approval This article does not contain any studies with human participants or animals performed by any of the authors.

Open Access This article is distributed under the terms of the Creative Commons Attribution 4.0 International License (http:// creativecommons.org/licenses/by/4.0/), which permits unrestricted use, distribution, and reproduction in any medium, provided you give appropriate credit to the original author(s) and the source, provide a link to the Creative Commons license, and indicate if changes were made.

\section{References}

1. Pratheeshkumar P, Sreekala C, Zhang Z et al (2012) Cancer prevention with promising natural products: mechanisms of action and molecular targets. Anti Cancer Agents Med Chem 12(10):1159-1184

2. Demain AL, Vaishnav P (2011) Natural products for cancer chemotherapy. Microb Biotechnol 4(5):687-699

3. Kinghorn AD, Chin YW, Swanson SM (2009) Discovery of natural product anticancer agents from biodiverse organisms. Curr Opin Drug Discovery Dev 12(2):189-196

4. Janakiram NB, Mohammed A, Rao CV (2015) Sea cucumbers metabolites as potent anti-cancer agents. Marine Drugs 13:2909-2023

5. Li YX, Himaya SWA, Kim SK (2013) Triterpenoids of marine origin as anti-cancer agents molecules. Molecules 18:7886-7909

6. Dyshlovoy SA, Honecker F (2015) Marine compounds and cancer: where do we stand? Marine Drugs 13:5657-5665

7. Bordbar S, Anwar F, Saari N (2011) High-value components and bioactives from sea cucumbers for functional foods. Marine Drugs 9:1761-1805

8. Aminin DL, Menchinskaya ES, Pisliagin EA, Silchenko AS, Avilov SA, Kalinin VI (2015) Anticancer activity of sea cucumber triterpene glycosides. Marine Drugs 13:1202-1223

9. Bahrami Y, Zhang W, Chataway T, Franco C (2014) Structural elucidation of novel saponins in the sea cucumber Holothuria lessoni. Marine Drugs 12:4439-4473

10. Bahrami Y, Zhang W, Franco C (2014) Discovery of novel saponins from the viscera of the sea cucumber Holothuria lessoni. Marine Drugs 12:2633-2667

11. Dyck SV, Gerbaux P, Flammang P (2010) Qualitative and quantitative saponin contents in five sea cucumbers from the Indian ocean. Marine Drugs 8:173-189

12. Park J, Bae HR, Kim CG, Stonik VA, Kwak JY (2014) Relationships between chemical structures and functions of triterpene glycosides isolated from sea cucumbers. Front Chem 2(77):1-14

13. Attoub S, Arafat K, Ge'laude A et al (2013) Frondoside a suppressive effects on lung cancer survival, tumor growth, angiogenesis, invasion, and metastasis. PLoS One 8(1):e53087

14. Zhao Q, Liu ZD, Xue Y et al (2011) Ds-echinoside A, a new triterpene glycoside derived from sea cucumber, exhibits antimetastatic activity via the inhibition of NF-KB-dependent MMP-9 and VEGF expressions. J Biomed Biotechnol 12(7):534-544

15. Atashrazm F, Lowenthal RM, Woods GM, Holloway AF, Dickinson JL (2015) Fucoidan and cancer: a multifunctional molecule with anti-tumor potential. Marine Drugs 13:2327-2346
16. Fitton JH, Stringer DN, Karpiniec SS (2015) Therapies from fucoidan: an update. Marine Drugs 13:5920-5946

17. Zhang SL, Li L, Yi YH, Zou ZR, Sun P (2004) Philinopgenin A, B, and $\mathrm{C}$, three new triterpenoid aglycones from the sea cucumber Pentacta quadrangulasis. Marine Drugs 2:185-191

18. Pomin VH (2015) Marine non-glycosaminoglycan sulfated glycans as potential pharmaceuticals. Pharmaceuticals 8:848-864

19. Pomin VH (2012) Fucanomics and galactanomics: marine distribution, medicinal impact, conceptions, and challenges. Marine Drugs 10:793-811

20. Wang XH, Zou ZR, Yi YH, Han H, Li L, Pan MX (2014) Variegatusides: new non-sulphated triterpene glycosides from the sea cucumber Stichopus variegates semper. Marine Drugs 12: 2004-2018

21. Sugawara T, Zaima N, Yamamoto A, Sakai S, Noguchi R, Hirata T (2006) Isolation of sphingoid bases of sea cucumber cerebrosides and their cytotoxicity against human color cancer cells. Biosci Biotechnol Biochem 70(12):2906-2912

22. Panagos CG, Thomson DS, Moss C et al (2014) Fucosylated chondroitin sulfates from the body wall of the sea cucumber Holothuria forskali. J Biol Chem 289(41):28284-28298

23. Dang NH, Thanh NV, Kiem PV, Huong LM, Minh CV, Kim YH (2007) Two new triterpene glycosides from the vietnamese sea cucumber Holothuria scabra. Arch Pharm Res 30:1387-1391

24. Zhang SL, Li L, Yi YH, Sun P (2006) Philinopsides E and F, two new sulfated triterpene glycosides from the sea cucumber Pentacta quadrangularis. Nat Prod Res 20(4):399-407

25. Baharara J, Amini E, Afzali M, Nikdel N, Mostafapour A, Kerachian MA (2016) Apoptosis inducing capacity of Holothuria arenicola in CT26 colon carcinoma cells in vitro and in vivo. Iranian J Basic Med Sci 19:358-365

26. Liu BS, Yi YH, Li L (2007) Arguside A: a new cytotoxic triterpene glycoside from the sea cucumber Bohadschia argus Jaeger. Chem Biodivers 4:2845-2851

27. Liu BS, Yi YH, Li L (2008) Argusides B and C, two new cytotoxic triterpene glycosides from the sea cucumber Bohadschia argus Jaeger. Chem Biodivers 5:1288-1297

28. Liu BS, Yi YH, Li L et al (2008) Argusides D and E, two new cytotoxic triterpene glycosides from the sea cucumber Bohadschia argus Jaeger. Chem Biodivers 5:1425-1433

29. Omran NEE, Khedr AM (2015) Structure elucidation, protein profile and the antitumor effect of the biological active substance extracted from sea cucumber Holothuria polii. Toxicol Ind Health 31(1):1-8

30. Zhang Y, Yi Y (2011) Studies on antitumor activities of triterpene glycoside colochiroside A from sea cucumber Colochirus anceps. Zhongguo Zhong Yao Za Zhi 36:504-550

31. Baharara J, Amini E, Nikdel N, Salek-Abdollahi F (2016) The cytotoxicity of dacarbazine potentiated by sea cucumber saponin in resistant B16F10 melanoma cells through apoptosis induction. Avicenna J Med Biotechnol 8(3):112-119

32. Menchinskaya ES, Pislyagin EA, Kovalchyk SN et al (2013) Antitumor activity of cucumarioside A2-2. Chemotherapy 59: 181-191

33. Jin JO, Shastina VV, Shin SW et al (2009) Differential effects of triterpene glycosides, frondoside A and cucumarioside A2-2 isolated from sea cucumbers on caspase activation and apoptosis of human leukemia cells. FEBS Lett 583:697-702

34. Zhao Q, Xue Y, Wang J et al (2012) In vitro and in vivo anti-tumour activities of echinoside $\mathrm{A}$ and $\mathrm{ds}$-echinoside $\mathrm{A}$ from Pearnonothuria graeffei. J Sci Food Agric 92:965-974

35. Li M, Miao ZH, Chen Z et al (2010) Echinoside A, a new marinederived anticancer saponin,targets topoisomerase $2 \alpha$ by unique interference with its DNA binding and catalytic cycle. Ann Oncol 21: 597-607

36. Janakiram NB, Mohammed A, Zhang Y, Choi CI, Woodward C, Collin P (2010) Chemopreventive effects of frondanol a5, a 
Cucumaria frondosa extract, against rat colon carcinogenesis and inhibition of human colon cancer cell growth. Cancer Prev Res 3(82):82-91

37. Roginsky AB, Ding XZ, Woodward C et al (2010) Anti-pancreatic cancer effects of a polar extract from the edible sea cucumber. Cucumaria frondosa Pancreas 39:646-652

38. Al Marzouqi N, Iratni R, Nemmar A et al (2011) Frondoside A inhibits human breast cancer cell survival, migration, invasion and the growth of breast tumor xenografts. Eur J Pharmacol 668:25-34

39. Li X, Roginsky AB, Ding XZ (2008) Review of the apoptosis pathways in pancreatic cancer and the anti-apoptotic effects of the novel sea cucumber compound, Frondoside A. Ann N Y Acad Sci 1138:181-198

40. Al Shemaili J, Parekh KA, Newman RA et al (2016) Pharmacokinetics in mouse and comparative effects of frondosides in pancreatic cancer. Marine Drugs 14(115):1-9

41. Al Shemaili J, Mensah-Brown E, Parekh K et al (2014) Frondoside A enhances the antiproliferative effects of gemcitabine in pancreatic cancer. Eur J Cancer 50:1391-1398

42. Silchenko AS, Avilov SA, Kalinin VI et al (2008) Constituents of the sea cucumber Cucumaria okhotensis. Structures of okhotosides B1-B3 and cytotoxic activities of some glycosides from this species. J Nat Prod 71:351-356

43. Dyshlovoy SA, Madanchi R, Hauschild J et al (2017) The marine triterpene glycoside frondoside $\mathrm{A}$ induces $\mathrm{p} 53$-independent apoptosis and inhibits autophagy in urothelial carcinoma cells. BioMed Central Cancer 17:93

44. Sun GQ, Li L, Yi YH et al (2008) Two new cytotoxic nonsulfated pentasaccharide holostane $(=20$-Hydroxylanostan-18-oic acid $\gamma$ lactone) glycosides from the sea cucumber Holothuria grisea. Helvetica Chimica Acta 91:1453-1460

45. J. Wu, Y. H. Yi, H. F. Tang, H. M. Wu, and Z. R. Zhou (2007) Hillasides A and B, two new cytotoxic triterpene glycosides from the sea cucumber Holothuria hilla lesson. J Asian Nat Prod Res 9(6-8), pp. 609-615

46. Althunibat OY, Hashim RB, Taher M, Daud JM, Ikeda MA, Zali BI (2009) In vitro antioxidant and antiproliferative activities of three Malaysian sea cucumber species. Eur J Sci Res 37(3):376-387

47. Han H, Xu QZ, Tang HF, Yi YH, Gong W (2010) Cytotoxic holostane-type triterpene glycosides from the sea cucumber Pentacta quadrangularis. Planta Med 76:1900-1904

48. Hossain Z, Sugawara T, Hirata T (2013) Sphingoid bases from sea cucumber induce apoptosis in human hepatoma HepG2 cells through p-AKT and DR5. Oncol Rep 29:1201-1207

49. Yun SH, Park ES, Shin SW et al (2015) By activating Fas/ceramide synthase 6/p38 kinase in lipid rafts, Stichoposide D inhibits growth of leukemia xenografts. Oncotarget 6(29):27596-27612

50. Zhang SY, Yi YH, Tang HF, Li L, Sun P, Wu J (2006) Two new bioactive triterpene glycosides from the sea cucumber Pseudocolochirus violaceus. J Asian Nat Prod Res 8(1-2):1-8

51. Cuong NX, Vien LT, Hoang L et al (2017) Cytotoxic triterpene diglycosides from the sea cucumber Stichopus horrens. Bioorg Med Chem Lett 27(13):2939-2942

52. Elmallah MIY, Micheau O (2015) Marine drugs regulating apoptosis induced by tumor necrosis factor-related apoptosis-inducing ligand (TRAIL). Marine Drugs 13:6884-6909

53. Safarzadeh E, Shotorbani SS, Baradaran B (2014) Herbal medicine as inducers of apoptosis in cancer treatment. Adv Pharm Bull 4(Suppl 1):421-427. https://doi.org/10.5681/apb.2014.062

54. Wargasetia TL, Shahib MN, Martaadisoebrata D, Dhianawaty D, Hernowo B (2015) Characterization of apoptosis and autophagy through Bcl-2 and Beclin-1 immunoexpression in gestational trophoblastic disease. Iranian Reprod Med 13(7):413-420

55. Wong RSY (2011) Apoptosis in cancer: from pathogenesis to treatment. J Exp Clin Cancer Res 30:87
56. Tong Y, Zhang X, Tian F et al (2005) Philinopside a, a novel marine-derived compound possessing dual anti-angiogenic and anti-tumor effects. Carcinogenesis 114(6):843-853

57. Tian F, Zhu CH, Zhang XW et al (2007) Phillinopside E, a new sulfated saponin from sea cucumber, blocks the interaction between kinase insert domain-containing receptor (KDR) and $\alpha v \beta 3$ integrin via binding to the extracellular domain of KDR. Mol Pharmacol 72: $545-552$

58. Yun SH, Park ES, Shin SW et al (2012) Stichoposide C induces apoptosis through the generation of ceramide in leukemia and colorectal cancer cells and shows in vivo antitumor activity. Clin Cancer Res 18:5934-5948

59. Seydi E, Motallebi A, Dastbaz M et al (2015) Selective toxicity of Persian gulf sea cucumber (Holothuria parva) and sponge (Haliclona oculata) methanolic extracts on liver mitochondria isolated from an animal model of hepatocellular carcinoma. Hepat Mon 15(12):e33073

60. Zhao Q, Xue Y, Liu Z et al (2010) Differential effects of sulfated triterpene glycosides, holothurin A1, and 24-dehydroechinoside A, on antimetastasic activity via regulation of the MMP-9 signal pathway. J Food Sci 75:280-288

61. Menchinskaya ES, Aminin DL, Avilov SA et al (2013) Inhibition of tumor cells multidrug resistance by cucumarioside A2-2, frondoside A and their complexes with a cholesterol. Nat Prod Commun 8:1377-1380

62. Janakiram NB, Mohammed A, Taylor B et al (2015) Improved innate immune responses by Frondanol ${ }^{\circledR}$ A5, a sea cucumber extract, prevent intestinal tumorigenesis. Cancer Prev Res 8:327-337

63. Ma X, Kundu N, Collin PD, Goloubeva O, Fulton AM (2012) Frondoside $\mathrm{A}$ inhibits breast cancer metastasis and antagonizes prostaglandin E receptors EP4 and EP2. Breast Cancer Res Treat 132:1001-1008

64. Park SY, Kim YH, Kim Y, and Lee SJ (2012) Frondoside A has an anti-invasive effect by inhibiting TPA-induced MMP-9 activation via NF- $\mathrm{kB}$ and AP-1 signaling in human breast cancer cells. Int J Oncol 41:933-940

65. Careaga VP, Bueno C, Muniain C, Alché L, Maier MS (2009) Antiproliferative, cytotoxic and hemolytic activities of a triterpene glycoside from Psolus patagonicus and its desulfated analog. Chemotherapy 55(1):60-68

66. Zou ZR, Yi YH, Wu HM, Wu JH, Liaw CC, Lee KH (2003) Intercedensides A-C, three new cytotoxic triterpene glycosides from the sea cucumber Mensamaria intercedens Lampert. J Nat Prod 66(8):1055-1060

67. Tian F, Zhang X, Tong Y et al (2005) PE, a new sulfated saponin from sea cucumber, exhibits anti-angiogenic and anti-tumor activities in vitro and in vivo. Cancer Biology \& Therapy 48:874-882

68. Zhong Y, Khan MA, Shahidi F (2007) Compositional characteristics and antioxidant properties of fresh and processed sea cucumber (Cucumaria frondosa). J Agric Food Chem 55:1188-1192

69. Collin PD Inhibition of angiogenesis by sea cucumber fractions. United States Patent 5,985,330, 16 November 1999

70. Patil M, Pabla N, Dong Z (2013) Checkpoint kinase 1 in DNA damage response and cell cycle regulation. Cell Mol Life Sci 70(21):4009-4021

71. Gabrielli B, Brooks K, Pavey S (2012) Defective cell cycle checkpoints as targets for anti-cancer therapies. Front Pharmacol 3:9

72. Gautam N, Mantha AK, Mittal S (2014) Essential oils and their constituents as anticancer agents: a mechanistic view BioMed Res Int Article ID 154106, 23 pages

73. Alaniz L, García M, Cabrera P, Arnaiz M, Cavaliere V, Blanco G, Alvarez E, Hajos S (2004) Modulation of matrix metalloproteinase9 activity by hyaluronan is dependent on NF- $\mathrm{kB}$ activity in lymphoma cell lines with dissimilar invasive behavior. Biochem Biophys Res Commun 324(2):736-743 